\title{
Biochemical and Haematological Parameters Among Gas Station Employees
}

\author{
Hatem Abdel Moniem Ahmed \\ Department of Forensic Chemistry, College of Forensic Sciences, Naif Arab University for Security Sciences, \\ Riyadh, Saudi Arabia
}

\begin{abstract}
Human exposure to heavy metals has significant harmful health effects and might be associated with the risk of blood abnormalities and biological parameters. The wasteful in the use of these metals was reached a high level of risk, leaving a huge burden on the environment. Therefore, the current study was designed to investigate any changes in the hematological and biochemical profile with the blood lead level among employees occupationally exposed to gasoline in different gas stations in Riyadh City. The exposed group included 35 gas station employees. They were compared to a corresponding group of healthy 35 male at the Department of Forensic Science, College of Criminal Justice, Naif Arab University for Security Sciences. The number of white blood cells, platelets, lymph, mean corpuscular volume, liver enzymes, Alanine transaminase, Aspartate Aminotransferase, and creatinine mean corpuscular hemoglobin were significantly higher with relatively small decreased in red blood cells, Haemoglobin, Mean corpuscular hemoglobin concentration and Hematocrit with increasing in the level of lead in gas stations employees compared to the control group.
\end{abstract}

Keywords: Lead, CBC, ALT, AST, creatinine.

DOI: $10.7176 / \mathrm{CMR} / 12-4-03$

Publication date: April $30^{\text {th }} 2020$

\section{Introduction}

Gasoline (petrol) consists mostly of organic compounds obtained by the fractional distillation of petroleum enhanced with different additives, whilst diesel is a specific fractional distillate of petroleum fuel oil which is a mixture of hydrocarbons (Donaldson et al., 2005). At the gas stations, workers have many hazards for their life because of their daily exposure to petrol, diesel and the inhalation of the fuel vapor for a long time, this lead too many respiratory system problems. It was reported that exposure to petroleum products and their vapors have been a highly toxic effect. The danger lies in the presence of some chemicals as benzene, lead $(\mathrm{Pb})$, and oxygenates which affect different body systems and the human respiratory system. The major exposure pathways of $\mathrm{Pb}$ through the inhalation and the ingestion of dust and vapors through $\mathrm{Pb}$-bearing. After absorption, $\mathrm{Pb}$ transferred to the blood, then accumulate in soft tissue, kidneys, bone marrow, liver, and brain, and deposited in bones (Herman et al., 2006).

The inhalation symptoms of gasoline include effects on the central nervous system, nose and throat irritation, hematological, headaches, hepatic, dizziness, renal, nausea, vomiting, confusion, lung functions, and breathing difficulties. The main effect of long exposure to benzene is on the blood, causing anemia, bleeding and increase the chance of infection, while The Department of Health and Human Services (DHHS) demonstrated that benzene has a role in causing human leukemia (Patel et al., 2004). Petroleum products and $\mathrm{Pb}$ content in the fuel having a negative impact on the organs of the body, there will be an evident impact on hematological parameters which we will investigate (Christian et al., 2016). New research has confirmed that the level of $\mathrm{Pb}$ below $50 \mu \mathrm{g} / \mathrm{dl}$ in the blood lead level (BLL) has toxic effects (Tak et al., 2008). The World Health Organization (WHO) Allowed $40 \mu \mathrm{g} / \mathrm{dl}$ as the highest BLL for adults (World Health Organization 1995), while the Centers for Disease Control (CDC) decreased the limit for BLL to $35 \mathrm{mcg} / \mathrm{d}-1$, as the highest of BLL for adults (CDC, 2008).

Different researchers showed that exposure to gasoline fume causes a reduction in hemoglobin $(\mathrm{Hb})$ level, hematocrit (Ht), and leukocytes in fuel attendants, which worsens with prolonged exposure (Okoro et al., 2006). Other researchers studied the hematological parameters in the workers who had been working in the gas stations for more than five years, Peripheral smear revealed basophilic punctuated erythrocyte and reticulocytosis. Hematological disturbance included mild white blood cells (WPCs) (7 of 37), lymphocytosis (an increase in the number of lymphocytes in the blood) (20 of 37), mild lymphopenia ( 3 of 37) and the decrease of erythrocytes count (11 of 37). These results significantly differed from those of controls (Pranjić et al., 2003).

Some researchers reported that there was a linear increase in red blood cells (RBCs) count and (WPCs) count with increasing BLL (Ovuru and Ekweozor 2004). Lately, some researchers observed when studying the chronic inhalation of petroleum products on hematological parameters a decrease in $\mathrm{Hb}$ level, erythrocytes, and total leucocyte counts and they proved that the chronic exposure to gasoline vapors has reverse effects on the human hematopoietic system (Aleemuddin et al., 2015). The effect of $\mathrm{Pb}$ on some liver enzymes has been studied by Kapaki, who proved that the level of Aspartate Aminotransferase (AST) and Alanine transaminase (ALT) were high in the gasoline stations employees, significantly lower activities were observed for ALP in 
occupationally exposed subjects were higher compared with controls.

The activities of ALT and AST in occupationally exposed subjects were higher compared with controls (Kales et al., 2001). Therefore, the current study was designed to investigate any changes in the hematological and biochemical profile in correlation to the BLL among employees occupationally exposed to gasoline.

\section{Material and Methods}

A comparative study was carried out on gas station employees at Riyadh City during the period from March 1, 2019, to June 31, 2019.

\subsection{Subjects}

The study included 35 out of 42 gas station employees; their age ranged between (20 and above 50 years) working in the gas stations between 20 and 30 years $(57.14 \%)$ and between 6 and 10 years $(48.57 \%)$, with a response rate of $93.33 \%$. Recruited from five gas stations located in Riyadh City, Saudi Arabia, were used as locations for this study and they represent the test subjects, all employees are males working in fueling service, with the average daily working hours ranged from 8 to 10 hours/day with an estimated average of 63 hours/week (Table 1) (Figure 1), who agreed to participate in the study. While 35 employees from Naif Arab University for Security Science, were recruited as a control group. The questionnaires were distributed and accurately filled by the participants with age, duration of work, safety measures. The gas station employees were met, and blood samples were taken at the managerial office at each station at 8 a.m.

Table 1. Mean values of duration working hours with age

\begin{tabular}{lcc}
\hline \multicolumn{1}{c}{ Age year } & Frequency & Percent \\
\hline $20-30$ & 20 & 57.14 \\
$31-50$ & 13 & 37.15 \\
above 50 & 2 & 5.71 \\
Total & 35 & 100.0 \\
\hline Duration working years & Frequency & Percent \\
\hline (6 month- 5 years) & 9 & 25.72 \\
(6 years-10 years) & 17 & 48.57 \\
(above 10) & 9 & 25.71 \\
Total & 35 & 100.0 \\
\hline
\end{tabular}

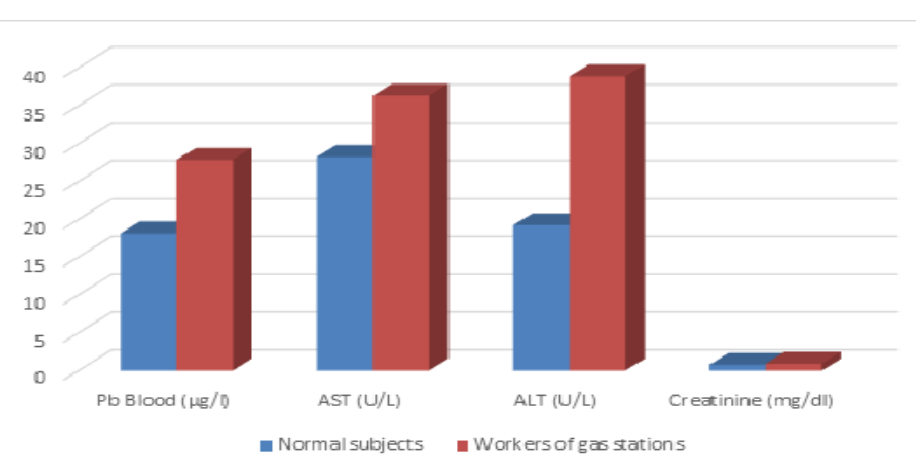

Figure 1. Duration working years with age.

\subsection{Ethical Consideration}

Endorsements of the gas stations, College of Criminal Justice, and the research ethics council were gotten. Educated verbal assent regarding study subjects to participate voluntarily in the study with a full right to withdraw, as they were eager to make a health check for free, was gotten with the confirmation of secrecy and namelessness of the information.

\subsection{Samples}

Nine $\mathrm{ml}$ of venous blood samples were from a peripheral vein on the arm of each subject. The blood divided into three portions, each portion has $3 \mathrm{ml}$ blood. The first portion collected in tubes with (anticoagulant EDTA) for complete blood picture, the second and third portions collected in a dry plastic tube for liver and kidney function tests (including urea, uric acid, and creatinine), liver function tests including (ALT, AST and creatinine activities) and lead analysis. The specimens were allowed to coagulate normally to isolate the serum for samples and were stored at room temperature until transporting to the laboratory for analysis. In the lab, each sample was centrifuged and put away in the freezer at $-70 \circ \mathrm{C}$ until being prepared. 


\subsection{Instrumentation}

The determination of $\mathrm{Pb}$ in blood was carried out using an ICP-OES (model: $5110 \mathrm{VDV}$, Agilent Technologies, and the USA), while all hematological parameters were measured using a fully automated Hematology analyzer Sysmax K-4500. Liver and kidney activities were determined using a UV test technique. ETHOS One ${ }^{\mathrm{TM}}$ Microwave Digestion System (Milestone Inc., USA) for blood digestion to determine $\mathrm{Pb}$.

\subsection{Hematological tests}

Hematological tests were performed using cell counter Sysmex KX21 to measure (Hb), (RBC) and (WBC) count. The values were then used for calculating Mean Corpuscular Volume (MCV) Mean Corpuscular Hemoglobin $(\mathrm{MCH})$ and Mean Corpuscular Hemoglobin Concentration (MCHC).

\subsection{Biochemical analysis}

(ALT), (AST) and creatinine were analyzed by using KENZA 240 TX/ISE chemical auto analyzer, BioLabo, France.

\subsection{Methods}

\subsubsection{Microwave digestion}

For the determination of lead in blood samples, the following was added in sequence in digestion vessels of the microwave oven; $1 \mathrm{ml}$ blood and $6 \mathrm{ml}$ distilled water. The contents were mixed by the vortex for 2 minutes before adding $5 \mathrm{ml} \mathrm{HNO}_{3}(69 \%)$ and $2 \mathrm{ml} \mathrm{H}_{2} \mathrm{O}_{2}(35 \%)$, and digested according to the procedure described by Piccinini (Piccinini et al., 2013). The blank followed the same extraction method. After preparing the samples, vessels were closed firmly and placed inside the microwave digestion oven. The ETHOS equipped with a temperature control was used for the sample digestion. The temperature program composed of $60 \mathrm{~min}$ at $200^{\circ} \mathrm{C}$ (power $1500 \mathrm{~W}$ ). The resulting solutions were cooled, filled up to $25 \mathrm{ml}$ with distilled water, filtered and analyzed by ICP-OES, where the samples were introduced in triplicates with the coupled Agilent SPS4 injector with a pump speed of $12 \mathrm{rpm}$. The instrument was operated under suitable conditions including choosing the suitable wavelength for $\mathrm{Pb}$ $(220.353 \mathrm{~nm})$ with calibration correlation coefficient limit of 0.998 , plasma argon flow rate of $121 / \mathrm{min}$, the auxiliary argon flow rate of $1 \mathrm{l} / \mathrm{min}$, nebulizer argon flow rate of $0.7 \mathrm{l} / \mathrm{min}$.

\subsubsection{Hematological tests}

The method was studied in smears prepared according to the procedure described by Sharma et al. (Sharma et al., 2012).

2.7.3 Biochemical analysis

Components such as creatinine, (AST) and (ALT) were determined according to Holding and Collee (Holding et al., 1971).

\subsection{Statistical analysis}

The statistical analysis used was an independent-test to compare means by SPSS Version 20.0 statistical software (SPSS Inc., Chicago, IL). The P-values of less than 0.05 were considered significant.

\section{Results}

The (Table 2) summarizes the t-test of blood lead and biochemical parameters (AST, ALT, and creatinine) between employees of gas stations and the control group, while the (Table 3) demonstrates the t-test of hematological parameters between gas stations employees and control group. The duration working with the age of the employees illustrated in the (Figure 1), while the values of BLL and biochemical parameters in the employees of gas stations with the control group displayed in the (Figure 2).

Table 2. T-test for BLL and biochemical parameters of both studies groups

\begin{tabular}{|c|c|c|c|c|c|c|}
\hline \multirow[b]{2}{*}{ Parameters } & \multirow[b]{2}{*}{$\begin{array}{c}\text { Control } \\
(\mathrm{N}=35)\end{array}$} & \multirow[b]{2}{*}{$\begin{array}{c}\text { Employees of gas } \\
\text { stations } \\
(\mathrm{N}=35) \\
\end{array}$} & \multicolumn{2}{|c|}{$\begin{array}{c}\text { Levene's Test for Equality of } \\
\text { Variances }\end{array}$} & \multicolumn{2}{|c|}{$\begin{array}{l}\text { t-test for Equality of } \\
\text { means }\end{array}$} \\
\hline & & & $\mathrm{F}$ & Sig. & $\mathrm{t}$ & $\begin{array}{l}\text { Sig. (2- } \\
\text { tailed) }\end{array}$ \\
\hline $\begin{array}{ll}\mathrm{Pb} & \text { Blood } \\
(\mu \mathrm{g} / \mathrm{l}) & \end{array}$ & $\begin{array}{l}18.15 \\
\pm 2.75\end{array}$ & $27.86 \pm 7.59 *$ & 32.97 & 0.000 & 7.11 & 0.000 \\
\hline AST (U/L) & $28.26 \pm 6.67$ & $36.34 \pm 7.57 *$ & 0.698 & 0.410 & 4.74 & 0.000 \\
\hline $\operatorname{ALT}(\mathrm{U} / \mathrm{L})$ & $19.23 \pm 4.32$ & $38.86 \pm 7.96^{*}$ & 10.81 & 0.002 & 12.83 & 0.000 \\
\hline $\begin{array}{l}\text { Creatinine } \\
(\mathrm{mg} / \mathrm{dl})\end{array}$ & $0.78 \pm 0.27$ & $0.92 \pm 0.29 *$ & 0.006 & 0.936 & 2.196 & 0.031 \\
\hline
\end{tabular}

\footnotetext{
$* \mathrm{P}<0.05$
} 
Table 3. T-test for of haematological parameters of both studies groups Independent samples test

\begin{tabular}{|c|c|c|c|c|c|c|}
\hline \multirow[b]{2}{*}{ Parameters } & \multirow[b]{2}{*}{$\begin{array}{l}\text { Control } \\
(N=35)\end{array}$} & \multirow[b]{2}{*}{$\begin{array}{c}\text { Employees of } \\
\text { gas stations (N } \\
=35)\end{array}$} & \multicolumn{2}{|c|}{$\begin{array}{l}\text { Levene's Test for } \\
\text { Equality of } \\
\text { Variances }\end{array}$} & \multicolumn{2}{|c|}{$\begin{array}{c}\text { t-test for Equality of } \\
\text { means }\end{array}$} \\
\hline & & & $\mathbf{F}$ & Sig. & $\mathbf{t}$ & $\begin{array}{l}\text { Sig. (2- } \\
\text { tailed) }\end{array}$ \\
\hline WBCs $\left(4-10 \times 10^{3}\right) \mathrm{u} / \mathrm{L}$ & $8.58 \pm 1.92$ & $8.63 \pm 2.28$ & 1.21 & 0.275 & 0.132 & 0.895 \\
\hline $\operatorname{RBCs}\left(4-5.5 \times 10^{6}\right) \mathrm{u} / \mathrm{L}$ & $5.30 \pm 0.19$ & $4.50 \pm 0.26^{*}$ & 3.80 & 0.054 & 13.70 & 0.000 \\
\hline $\mathrm{Hb}(12-16) \mathrm{g} / \mathrm{dl}$ & $15.15 \pm 1.17$ & $12.45 \pm 1.13^{*}$ & 0.07 & 0.800 & 9.76 & 0.000 \\
\hline Lymph $20-40 \%$ & $34.72 \pm 4.56$ & $38.35 \pm 6.61 *$ & 2.25 & 0.138 & 2.68 & 0.009 \\
\hline $\begin{array}{l}\text { Platelets uL } \times 10^{3} \\
300)\end{array}$ & $246.80 \pm 5.69$ & $302.09 \pm 12.42 *$ & 23.97 & 0.000 & 23.94 & 0.000 \\
\hline $\mathrm{MCHC}$ g/dL (32-36) & $35.47 \pm 0.68$ & $35.33 \pm 0.83$ & 0.17 & 0.682 & 0.744 & 0.459 \\
\hline MCH Pg $\quad(27-34)$ & $27.47 \pm 2.36$ & $23.99 \pm 2.60 *$ & 4.16 & 0.045 & 5.8 & 0.000 \\
\hline Mcv fL (80-100) & $83.82 \pm 4.63$ & $85.57 \pm 1.9 *$ & 5.5 & 0.022 & 2.07 & 0.004 \\
\hline Hematocrit \% (40-54) & $42.19 \pm 7.5$ & $44.10 \pm 6.08$ & 0.51 & 0.477 & 1.17 & 0.247 \\
\hline
\end{tabular}

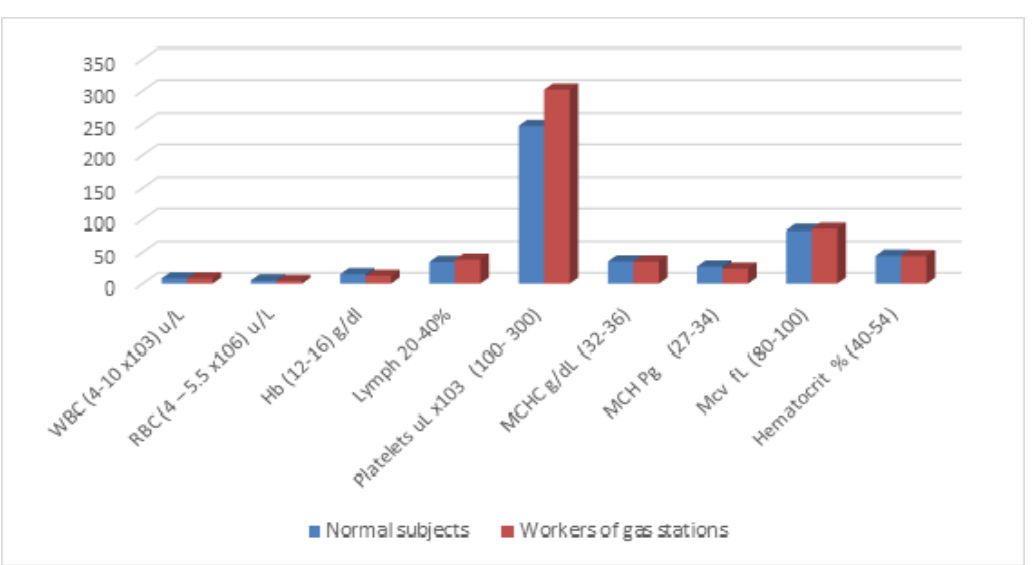

Figure 2. Values of BLL and biochemical parameters of both studies groups

\section{Discussion}

A relation between exposure to mixtures containing gasoline and certain types of blood disorders have been shown in many countries through epidemiological researches (Lan et al., 2005). Employees who worked in gasoline stations are regularly exposed to many harmful toxic heavy metals as $\mathrm{Pb}$ which causes abnormal changes in the functioning of many vital organs, and they are associated with increased risk of heme-biosynthesis related parameters (Ali et al., 2013). Unfortunately, the majority of the employees are neglecting or lacking protective safety measures such as; face masks, protective cloths, gloves and washing after finishing their working shift. In turn, this carelessness makes them more susceptible to those toxic fumes.

In the United States, $\mathrm{Pb}$ has been completely eliminated from all engine fuel, since 1990, and most Western European countries have reduced the $\mathrm{Pb}$ content in gasoline to $(0.4 \mathrm{~g} / \mathrm{l})$. Since 1986 , further reduction of $\mathrm{Pb}$ has been planned to $(0.15 \mathrm{~g} / \mathrm{l})$, as in Japan $96 \%$ of the gasoline is unleaded. Riyadh refinery in Saudi Arabia produces about $(30 \%)$ of the total domestic gasoline and the average $\mathrm{Pb}$ level in the manufacture gasoline is approaching $(0.30 \mathrm{~g} / \mathrm{l})$. The lead content of benzene in Riyadh $(0.84 \mathrm{~g} / \mathrm{l})$ is higher than the international level and is now gradually reduced to $(0.42 \mathrm{~g} / \mathrm{l})$ which is still higher than the international level (Ibrahim et al., 2012). It was reported that $\mathrm{Pb}$ toxicity probably leads to malaise, anorexia, vomiting, abdominal pain, constipation, colic, lethargy, apathy, irritability, weakness, generalized fatigue and the next were prickle and anesthesia of leg or arm, feeling agitated at the slightest disorder, and weakness of wrist or ankle joint are the most symptoms which were found among $\mathrm{Pb}$ gas stations employees (Gordon et al., 2002). The symptoms of depression and decreased and motor abilities were identified in employees of the Croatian gas station who had exposed to leaded gasoline for more than five years (Pranjić et al., 2003).

Several studies have reported that $\mathrm{Pb}$ exposure has toxic effects on humans, and most of these studies have observed a link between signs and symptoms of the disease and levels of $\mathrm{Pb}$ in the blood, in addition, the concentration of $\mathrm{Pb}$ in the blood has an important relationship with pellets white and red blood, where high BLL causes cracking of (RBCs) (Toplan et al., 2004).

The BLL is generally vastly used for the measure of $\mathrm{Pb}$ exposure and consider the best biomarker for 
determination and distinguishing $\mathrm{Pb}$ contamination, and generally, reflects acute (current) exposure (Sommar et $a l ., 2014)$. In this study, the mean BLL of gas stations employees $(27.86 \pm 7.59 \mu \mathrm{g} / \mathrm{l})$ was significantly higher than that of the control group $(18.15 \pm 2.75 .75)$, ( $\mathrm{t}$-test=7.11), (P-value=0.00) (table 2). The mean duration exposure was $(7.58 \pm 4.39 .39)$, this means that the higher the exposure period, the higher Pb level in the blood. These results were agreed with the results reported in a study of employees exposed to professional work at gas stations (Nuwayhid et al., 2001). Our results are also much higher than the results reported in other countries such as Denmark and Ghana (3.5 and $8.6 \mu \mathrm{g} / \mathrm{dl})$ respectively (Kales et al., 2001).

Blood parameters like Hct, Hb, RBCs, WBCs, Mcv, MCHC, MCH, PLTs, enzymes activities as AST, ALT, and creatinine, are taken as an indicator of heavy metal contamination in polluted environments (Shah and Altindag 2004). The data available in this study are consistent with the previous study, where the mean of (RBCs) counts was decreased in employees $(5.17 \pm 0.353)$ with the increase in BLL, and statistically significant (ttest=13.75) (P-value $=0.00)$ (Table 3), which agree with Sahb (Sahb, 2011). In the case of (WBCs), no statistically significant differences in the mean number of (WBCs) between the control group and gas station employees, where the value of the (t-test and p-value) was $(0.132,0.895)$, respectively. The results of the current study were consistent with Ragini, who indicated that the number of (WBCs) did not change with increasing BLL of gas stations employees $(8.63 \pm 2.28)$ compared with the control group $(8.58 \pm 1.92)$ (table 3) (Figure 2) (Ragini et al., 2012).

$\mathrm{Hb}, \mathrm{Ht}$ and $\mathrm{MCH}$ levels were significantly decreased with increasing of BLL. Some studies have suggested that high BLL causes anemia by inhibiting $\mathrm{Hb}$ production and shortening the life of (RBCs) (Shah and Altindag 2004). This was revealed by this study that, there was a significant difference between $\mathrm{Hb}$ and $\mathrm{MCH}$ in tested samples and control group $(12.45 \pm 1.13$ and $23.99 \pm 2.6 .6)$ and $(15.15 \pm 1.17$ and $27.47 \pm 2.36 .36)$, respectively, while no significant differences in Ht between control subjects and tested samples (44.49 \pm 6.49 and $44.10 \pm$ 6.08.08), where the value of (t-test and P-value) are $(9.76,0.00),(0.261,0.795)$ and $(5.8,0.00)$, respectively (Table 3) (Figure 3). This is also consistent with Krishna and Ramachandran who showed that exposure of $\mathrm{Pb}$ causes anemia in rats (Krishna and Ramachandran 2009). The reason for the anemia due to exposure to $\mathrm{Pb}$ has been associated with its ability to decrease serum iron concentration thereby interfering with hemoglobin synthesis (Goel et al., 2006). BLL is bounded with negative health effects when reaching (100 to $200 \mu \mathrm{g} / \mathrm{l})$ and can lead to damage to the hematopoietic, kidney, endocrine, and reproductive system (Assi et al., 2016).

Previous studies have also revealed that a relatively high Mcv and lower MCHC ratio indicates the presence of anemia with increasing exposure to $\mathrm{Pb}$ (Ambali et al., 2010), this consistent with present study, where it was observed that a relatively significant increase of Mcv $(85.57 \pm 1.9 .9)$ and a small decrease in MCHC (35.33 \pm 0.83 .83 ) between the control group and gas stations employees, where (t-test and p-value) $(2.07,0.744)$ and $(0.459,0.04)$ for Mcv and MCHC respectively (table 3$)$. PLTs or Thrombocytosis (PLTs count means that the presence of high platelet counts in the blood) is fragments of cytoplasm; they derived from large bone marrow with another type of blood cells; it consider a diagnostic tool for assessing platelet diseases and its analysis and evaluation allows the determination of several parameters, especially in bleeding patients or in the presence of thrombocytopenia or extreme thrombocytosis (Stokol, 2010). Seriki et al. indicate in his research that gasoline may have an important role in stimulating the efficiency of the bone marrow to produce more PLTs (Seriki et al., 2016). The increase of platelet (thrombocyte) count in the blood leads to Thrombocythemia (is a condition of high platelet count in the blood) (Altomare and Kessler 2019), which leads to megakaryocyte proliferation and acute hemorrhage (Stokol, 2010; Levine et al., 2005). The previous study agrees with the current study, where PLTs were higher in gas station employees than the control group (302.09 \pm 12.42 and $246.80 \pm 5.69 .69)$ respectively (Table 3), and statistically significant $(\mathrm{t}$-test $=23.94$, P-value $=0.00)$ (Table 3).

$\mathrm{Pb}$ may cause immune modification and effects in humans, although the mechanisms inside the body are not well understood. $\mathrm{Pb}$ is considered as an important environmental and occupational poison (John et al., 2006). This study revealed that the ratio of lymphocytes in gas stations employees higher than the control group ( 38.35 \pm 6.61 and $34.72 \pm 4.56 .56)$ respectively and statistically significant (t-test=2.68, P-value $=0.009)($ Table 3$) . \mathrm{Pb}$ present in gasoline leads to liver cell damage because having a hepatotoxic effect, which leads to increase serum levels of AST and ALT (Abdou et al., 2007).

High levels of AST and ALT plasma is related to high alteration in the liver cells and production of liver microsomal membrane fluidity and free radicals when animals were exposed to lead level (Ibrahim et al., 2012). One study found that fuel station employees suffered from liver disorders: chronic fatty liver degeneration, functional liver damage, and liver cirrhosis (Pranjić et al., 2003). The results of this study showed that AST and ALT enzymes in gas stations employees were higher than the control group $(36.34 \pm 7.57$ and $38.86 \pm 7.96 .96)$ and $(28.26 \pm 6.67$ and $19.23 \pm 4.32 .32)$ respectively, and statistically significant $(\mathrm{t}-\mathrm{test}=4.74$ and 12.83$)(\mathrm{P}-$ value $=0.00$ and 0.00 ), respectively (Table 3). The enzyme's activities were higher with the elevation of lead exposure. This can happen because of increased cell membrane damage or cell membrane permeability of hepatocytes under the influence of exposure to lead elements (Ovuru and Ekweozor 2004). The results of this study are consistent with some studies, which proved an increase in ALT and AST levels after exposure to lead 
(Patil et al., 2007).

On the other hand, the concentration of creatinine was examined to check how kidney work. An increase in blood creatinine level was detected in gas stations employees $(0.92 \pm 0.29 .29)$ compared with the control group $(0.78 \pm 0.27 .27)$ and statistically significant (t-test $=2.2, \mathrm{P}$-value $=0.03)($ Table 3$)$. This height may be due to kidney dysfunction and considered functional evidence of lead-induced nephrotoxicity (Odigie et al., 2004).

\section{Conclusion}

The levels of blood lead are slightly elevated among gasoline stations employees in Riyadh City. As well as, hemoglobin level and red blood cells count had lower in the employees. While other hematological parameters were significantly elevated. The level of serum ALP and creatinine were significantly higher among the employees. A clear educational and protection policy are required for those who are occupationally exposed to benzene and other noxious gasoline vapors.

\section{References}

Donaldson, K., Tran, L., Jimenez, L. A., Duffin, R., Newby, D. E., Mills, N., ... \& Stone, V. (2005). Combustion-derived nanoparticles: a review of their toxicology following inhalation exposure. Particle and fibre toxicology, 2(1), 10.

Herman DS, Geraldine M, Scott CC, enkatesh T V. Health hazards by lead exposure: evaluation using ASV and XRF. Toxicol Ind Health. 2006; 22(6): 249-254.

Patel A S, Talbott E O, Zborowski J V, Rycheck J A, Dell D, Xu X, et al. (2004). Risk of cancer as a result of community exposure to gasoline vapors. Arch Environ Health 59 (10): 497-503.

Christian SG, Elekima I, Obisike UA, Aleru CP. Effect of Petroleum on Haematological Parameters and Lead Level in Fuel Attendants in Port Harcourt, Nigeria. International Journal of Science and Research. 2016; 5 (3).

Tak, S., Roscoe, R. J., Alarcon, W., Ju, J., Sestito, J. P., Sussell, A. L., \& Calvert, G. M. (2008). Characteristics of US workers whose blood lead levels trigger the medical removal protection provision, and conformity with biological monitoring requirements, 2003-2005. American journal of industrial medicine, 51(9), 691700 .

World Health Organization. Biological indices of lead exposure and body burden. In: IPCS, inorganic lead environmental health criteria 118,$1995 ; 165: 114-8$.

CDC. Screening young children for lead poisoning: Guidance for state and local public health officials. Centers for Disease Control and Prevention. Available at: http://www.cdc.gov/nceh/lead/guide/guide 97.htm, accessed October 6, 2008.

Okoro, A. M., Ani, E. J., Ibu, J. O., \& Akpogomeh, B. A. (2006). Effect of petroleum products inhalation on some haematological indices of fuel attendants in Calabar metropolis, Nigeria. Nigerian Journal of Physiological Sciences, 21(1-2).

Pranjić, N., Mujagić, H., \& Pavlović, S. (2003). Inhalation of gasoline and damage to health in workers at gas stations. Medicinski arhiv, 57(1), 17-20.

Ovuru, S. S., \& Ekweozor, I. K. E. (2004). Haematological changes associated with crude oil ingestion in experimental rabbits. African Journal of Biotechnology, 3(6), 346-348.

Aleemuddin M, Babu MG, Manjunath ML, Quadri SS. Effect of Chronic Inhalation of Petroleum Products on Haematological Parameters. International Journal of Current Research and Academic Review. 2015; 3 (4): 196-201.

Kales SN, Polychronopoulos GN, Aldrich JM, Mendoza PJ, Suh JH, Christiani DC. Prospective study of hepatic, renal, and haematological surveillance in hazardous materials firefighters. Occup Environ Med. 2001; 58:87-94.

Piccinini P, Piecha M, Torrent SF. European survey on the content of lead in lip products. J. Pharm. Biomed. Anal. 2013; 76: 225.

Sharma R, Panwar K, Mogra S. Effects of prenatal and neonatal exposure to lead on white blood cells

Holding AJ, Collee JG. Chapter I Routine biochemical tests. In Methods in microbiology.1971; 6:1-32. Academic Press.

Lan, Q., Zhang, L., Shen, M., Smith, M. T., Li, G., Vermeulen, R., \& Dosemeci, M. (2005). Polymorphisms in cytokine and cellular adhesion molecule genes and susceptibility to hematotoxicity among workers exposed to benzene. Cancer research, 65(20), 9574-9581

Ali K A, Sultan R, Zamani GY, Rahman SU. Biochemical and Hematological Analysis after Exposure to Hazardous Materials during Shoe Making. Journal of Biology and Life Science. 2013; 4 (2): 116-28.

Ibrahim NM, Eweis EA, El-beltagi HS, Abdel- Mobdy YE. Effect of lead acetate toxicity on experimental male albino rat. Asian Pas Trop Biomed. 2012; 2: 41-46.

Gordon JN, Taylor A, Bennett PN. Lead poisoning: case studies. Br J Clin Pharmacol. 2002; 53 (5): 451-458. 
Toplan S, Ozcelik D, Gulyasar T, Akyolcu MC. Changes in hemorheological parameters due to lead exposure in female rats. J Trace Elem Med Biol. 2004; 18 (2): 179-82.

Sommar JN, Hedmer MT, Nilsson L, Skerfving S, Bergdahl IA. Investigation of lead concentrations in whole blood, plasma and urine as biomarkers for biological monitoring of lead exposure. J Expo Sci Environ Epidemiol. 2014; 24(1):51-7.

Nuwayhid I, McPhaul K, Bu-Khuzam R, Duh SH, Christenson RH, Keogh JP. (2001). Determinants of elevated blood lead levels among working men in Greater Beirut. J Med Liban. 2001; 49 (3):132-9.

Shah, S. L., \& Altindag, A. (2004). Hematological parameters of tench (Tinca tinca L.) after acute and chronic exposure to lethal and sublethal mercury treatments. Bulletin of environmental contamination and toxicology, 73(5), 911-918.

Sahb, A. A. (2011). Hematological assessment of gasoline exposure among petrol filling workers in Baghdad. Journal of the Faculty of Medicine, 53(4), 396-400.

Ragini S, Khushbu P, Sheetal M. Effects of prenatal and neonatal exposure to lead on white blood cells in Swiss mice. Journal of Cell and Molecular Biology. 2012; 10 (1): 33-40.

Krishna H, Ramachandran AV. Biochemical alterations induced by the acute exposure to combination of chlorpyrifos and lead in Wistar rats. Biol Med. 2009; 1(2): 1-6.

Goel, A., Dani, V., \& Dhawan, D. K. (2006). Role of zinc in mitigating the toxic effects of chlorpyrifos on hematological alterations and electron microscopic observations in rat blood. Biometals, 19(5), 483-492.

Assi, M. A., Hezmee, M. N. M., Haron, A. W., Sabri, M. Y. M., \& Rajion, M. A. (2016). The detrimental effects of lead on human and animal health. Veterinary world, 9(6), 660.

Ambali SF, Abubakar AT, Shittu M, Yaqub LS, Anafi SB, Abdullahi A. Chlorpyrifos-induced alteration of hematological parameters in Wistar rats: ameliorative effect of zinc. Res J. of Environ Toxicol. 2010; 4 (2): 55-66.

Stokol T. Essential thrombocythemia and reactive thrombocytosis. Schalm's veterinary hematology. 6th edition. Philadelphia: Blackwell Publishing. 2010; 605-11.

Seriki SA, Adebayo OF, Shafe MO, Bivan ZK. Effects of Gasoline Poisoning on Some Hematological Parameters. Ann Hematol Oncol. 2016; 3(4): 1087.

Altomare, I., \& Kessler, C. M. (2019). Thrombocytosis: Essential Thrombocythemia and Reactive Causes. In Consultative Hemostasis and Thrombosis (pp. 346-373). Content Repository Only!.

Levine, R. L., Wadleigh, M., Cools, J., Ebert, B. L., Wernig, G., Huntly, B. J., ... \& Adelsperger, J. (2005). Activating mutation in the tyrosine kinase JAK2 in polycythemia vera, essential thrombocythemia, and myeloid metaplasia with myelofibrosis. Cancer cell, 7(4), 387-397.

John BC, Ashley A, Frank NP. Immune Modulation by Cadmium and Lead in the Acute Reporter AntigenPopliteal Lymph Node Assay. Toxicological Sciences. 2006; 91(1): 113-122.

Abdou ZA, Attia MH, Raafat MA. Protective effect of citric acid and thiol compounds against cadmium and lead toxicity in experimental animals. J Biol Chem Environ Sci. 2007; 2: 481-497.

Patil AJ, Bhagwat VR, Patil JA, Dongre NN, Ambekar JG, Das KK. Occupational lead exposure in battery manufacturing workers, silver jewelry workers, and spray painters in western Maharashtra (India): effect on liver and kidney function. J Basic clin Physiol Pharmacol. 2007; 18: 87-100.

Odigie, I. P., Ladipo, C. O., Ettarh, R. R., \& Izegbu, M. C. (2004). Effect of chronic exposure to low levels of lead on renal function and renal ultrastructure in SD rats. Nigerian Journal of Physiological Sciences, 19(1), 27-32.

\section{Biography of Dr. Hatem Ahmed}

Associate Professor of Applied Chemistry - Dean of the College of Criminal Justice - Naif Arab University for Security Sciences - Saudi Arabia. I have 24 scientific research in the field of applied chemistry (toxic elements and pesticides). Supervising 22 master's theses and discussing 17 master theses. Participation in about 38 participation between conferences, seminars, workshops, forums, scholarships, and training courses in the field of toxicology and drug analysis. 